og ubehandlet hjem igjen. Jeg fikk flere ganger følelsen av ikke å bli trodd. Jeg forsto at jeg ikke kom til å få hjelp, siden jeg stadig fikk beskjed om at jeg måtte «lære meg å leve med» plagene mine. Jeg var ikke enig, smertene var for voldsomme. Flere ganger ble jeg forklart at plagene hadde psykiske årsaker.

Jeg måtte si fra meg arbeidet som gruppeleder på jobben og byttet arbeidsoppgaver i håp om at det kunne gi bedring, men det hjalp ikke. Jeg la meg tidlig om kvelden og klarte så vidt å stå opp og gå på jobb. Det føltes nedverdigende å sitte på jobben og være syk. Jeg fikk problemer med å fungere i familien, på jobben og sosialt ellers, følte meg utslitt og gikk ned i vekt.

\section{Kan det være nyren?}

Min datter er bioingeniør og undersøkte, sammen med overlegen ved laboratoriet der hun arbeidet, en urinprøve fra meg etter et smerteanfall. Den viste «rikelig med intakte erytrocytter, uttrykk for en postglomerulær hematuri». Overlegen hadde tidligere sett et tilfelle med symptomatisk vandrenyre (ren mobilis) og mistenkte at dette også kunne gjelde meg. Etter konferanse med urolog ble det kartlagt nærmere.

Det ble anbefalt røntgen i liggende og stående stilling ved smerteanfall, for om mulig å påvise redusert avløp fra nyren og for eventuelt å påvise mobil nyre. Jeg klarte aldri å få organisert røntgenundersøkelse ved smerteanfall pga. reiseavstand og åpningstider ved røntgeninstituttet. Det ble således ikke påvist eventuelt redusert avløp fra nyren. Ved urografi ble det konstatert mobil høyre nyre, først med nyreforflytning på $2,6 \mathrm{~cm}$, senere med $4,4 \mathrm{~cm}$. Renografi viste nyreforflytning på $4-5 \mathrm{~cm}$. Etter å ha lest mange artikler i engelskspråklige medisinske tidsskrifter om vandrenyre, ble jeg overbevist om at dette kunne være årsaken til mine invalidiserende plager.

Jeg ba om operasjon for mulig avbøting av plagene, men det ble avslått i 2008, da legene mente at man ikke hadde holdepunkter for at smertene skyldtes vandrenyre. Jeg var igjen på bar bakke - like syk som før og fullstendig utslitt. Arbeidsgiver aksepterte ikke lenger sykdommen min. Det ble stilt krav som jeg pga. plagene vanskelig kunne innfri, og jeg så meg selv på vei ut fra arbeidsforholdet. Jeg søkte om å bli utredet ved et sykehus med erfaring med tilstanden i Sverige, men søknaden ble avslått.

Jeg ga uttrykk for at jeg ikke lenger orket å leve med plagene. Operasjonen laparoskopisk nefropeksi ble til slutt tilbudt, på eget ansvar. Jeg ble operert i februar 2009, og kirurgen beskrev «multiple adheranser mellom colon og bukvegg på høyre side». Adheransene ble løsnet. Nyren ble festet så høyt i buken kirurgen klarte.

Etterpå ble de fleste smerteplagene borte.
Jeg har fått et mye bedre liv, og livet føles igjen verdt å leve. Jeg har lagt på meg, er fysisk aktiv, går tur, jogger og arbeider i $70 \%$ stilling. Urinen har vært klar og fin. Hematurien er borte. De sprengte blodkarene $i$ ansiktet er nesten borte, mandlene er ikke lenger hovne og blodtrykket er normalt.

Det virker som om symptomatisk vandrenyre er lite kjent blant leger i Norge, og det synes å mangle utredningsprosedyrer. Jeg vil tro det er flere enn meg som helt unødig har gått med slike forferdelige plager. Jeg håper at min historie kan være med på å gjøre diagnosen bedre kjent blant helsepersonell.

\section{Kari Tuft Stavnes}

kstavnes@online.no

Kvernberggata 39

Hønefoss

Kari Tuft Stavnes (f. 1956) er saksbehandler i Skatt Sør.

Mottatt 5.7. 2011, første revisjon innsendt 23.11 2011, godkjent 1.12. 2011. Medisinsk redaktør Erlend Hem.

\title{
Symptomgivende vandrenyre kan både diagnostiseres og behandles
}

Kari Stavnes gir en god beskrivelse av en tilstand som har vært gjenstand for mye diskusjon i medisinsk litteratur. Hun beskriver godt en del av de typiske ledsagersymptomene hun har opplevd, men enda bedre fortvilelsen over at hennes plager ikke blir gjenkjent og behandlet før etter mange år.

Hun mener tilstanden er lite kjent blant leger og dermed ikke blir diagnostisert. Vandrenyre er i nyere tid omhandlet i Tidsskriftet ved to anledninger $(1,2)$. Tilstanden går under mange navn: nefroptose, ren mobile, ren migrans, Wanderniere, floating kidney. Rundt forrige århundreskifte ble den (for) hyppig diagnostisert og operert, noe som ledet til at inngrepet, nefropeksi, kom i miskreditt. Nå finnes det bedre diagnostiske metoder slik at inngrepet kan begrunnes på en mer sikker måte (3).

\section{Smerter er hovedsymptom}

Nyrene beveger seg ved overgang fra liggende til stående stilling, dessuten ved hvert eneste åndedrag som følge av diafragmabevegelse. Hos enkelte kan bevegelsen være eksessiv og gi opphav til plager. Ofte angis at bevegelse på $>5 \mathrm{~cm}$ eller mer enn to virvelhøyder er patologisk. De fleste med så stor bevegelighet er uten symptomer, men det antas at $20 \%$ kan ha symptomer og behov for behandling (3). Smertene antas å være forårsaket av obstruksjon i overgangen nyrebekken-ureter, grunnet avklemming når nyren faller ned - med påfølgende trykkstigning, som kan lede til hydronefrose. Når nyren endrer leie, blir karstilken forlenget - med avsmalning av nyrearterien med påfølgende nyreiskemi, som i sin tur kan lede til hypertoni (Goldblatt-nyre) (3-5). Om tilstanden vedvarer over lang tid, antas den å kunne forårsake fibromuskulær dysplasi, med nyrearteriestenose til følge.

Den typiske pasient er en ung, slank kvinne som klager over varierende grad av smerter i høyre abdominalhalvdel eller flanke som typisk opptrer i stående stilling og under aktivitet, med lindring når hun legger seg ned. Noen kan typisk ha smerter når de ligger på venstre side, med lindring ved å ligge på høyre side. Noen pasienter opplever (gjentatte) nyrebekkenbetennelser.

Smerteangivelsen kan variere fra den kolikkartede (Dietls krise) til dumpe, stikkende smerter i stående eller sittende stilling med lindring når man ligger. Mange opplever kraftig kvalme, noen med brekninger. Hos slanke pasienter kan ofte nyren palperes under kostalbuen i stående stilling eller i kne-albue-leie, nyren er ofte palpasjonsøm og balloterer mer enn normalt $(3,6,7)$.

\section{Undersøkelse}

Ved undersøkelse kan man finne varierende grad av hematuri og hypertensjon, hos noen bare i stående stilling. Den typiske pasient er undersøkt for mistenkt nyresteinsanfall uten å få påvist nyrestein. 
For å avdekke tilstanden bør det gjøres urografi med væskebelastning, eventuelt med furosemid, og med bilder i stående og liggende stilling. Ved isotoprenografi kan man finne sidelik nyrefunksjon i liggende stilling med tydelig funksjonsinnskrenkning i den affiserte nyren i stående stilling. Hos enkelte pasienter kan forhøyede reninnivåer (i stående stilling) påvises.

Dersom pasienten har symptomer og får påvist slike funksjonsforstyrrelser, er dette operasjonsindikasjon. Man kan, dersom det hersker usikkerhet om hvorvidt symptomene kan relateres til tilstanden, gjøre en «prøvebehandling». I liggende stilling kan man ta på en stram elastisk bukse som når over navlenivå og legge en svamp like over lysken, noe som vil hindre nyren i å senkes i oppreist stilling. Gir dette symptomlindring, styrker det indikasjonen for behandling.

\section{Behandling}

Behandlingen er operativ - med flere tilnærminger for å fiksere nyren for å motvirke den overdrevne bevegeligheten. Dette kan gjøres perkutant med temporært perku- tant nyredren, med åpen operasjon eller laparoskopisk. Ved de siste to alternativer fjerner man capsula adiposa renis fra nyrens dorsalflate og fikserer deretter nyren til fascien ventralt for $\mathrm{m}$. quadratus lumborum. Ved klare symptomer og funn gir inngrepet bedring hos $80 \%(1-3)$.

\section{Jan Due}

jan.due@unn.no

Avdeling urologi og endokrinkirurgi

Universitetssykehuset Nord-Norge og

Institutt for klinisk medisin

Det helsevitenskapelige fakultet

Universitetet i Tromsø

Jan Due (f. 1942) er spesialist i generell kirurgi og urologi, overlege ved Avdeling urologi og endokrin kirurgi, Universitetssykehuset NordNorge, og amanuensis ved Institutt for klinisk medisin, Det helsefaglige fakultet, Universitetet i Troms $\varnothing$.

Ingen oppgitte interessekonflikter.
Litteratur

1. Kvarstein B, Mathisen W. Nefroptose. Tidsskr Nor Lægeforen 1979; 99: 1185-6.

2. Almdahl SM, Due J. Vandrenyre. Tidsskr Nor Lægeforen 1985: 105: 809-10.

3. Srirangam SJ, Pollard AJ, Adeyoju AA et al. Nephroptosis: seriously misunderstood? BJU Int 2009; 103: 296-300

4. Goldblatt H, Lynch J, Hanzal RF et al. Studies on experimental hypertension: I. The production of persistent elevation of systolic blood pressure by means of renal ischemia. J Exp Med 1934; 59 : 357-79. www.ncbi.nlm.nih.gov/pmc/articles/ PMC2132360 (23.1.2012).

5. de Zeeuw D, Donker AJ, Burema J et al. Nephroptosis and hypertension. Lancet 1977; 1: 213-5.

6. Dietl J. Wandernde Nieren und deren Einklemmung. Wien Med Wschr 1864; 14: 563.

7. Narath PA. Nephroptosis. Urol Int 1961; 12: 164-90.

Mottatt 9.1.2012 og godkjent 19.1.2012. Medisinsk redaktør Erlend Hem. 